\title{
Influence of Malnutrition on Adverse Outcome in Children with Confirmed or Probable Viral Encephalitis: A Prospective Observational Study
}

\author{
Priyanka Singh, ${ }^{1}$ Girish C. Bhatt, ${ }^{2}$ Vijay Singh, ${ }^{1}$ K. P. Kushwaha, ${ }^{1}$ Mahima Mittal, ${ }^{1}$ \\ Anita Mehta, ${ }^{1}$ Bhoopendra Sharma, ${ }^{1}$ Abhijit P. Pakhare, ${ }^{3}$ and Abhishek Kumar ${ }^{1}$ \\ ${ }^{1}$ Department of Pediatrics, BRD Medical College, Gorakhpur, India \\ ${ }^{2}$ Department of Pediatrics, All India Institute of Medical Sciences (AIIMS), Room No. 10, OPD Block, Saket Nagar, Bhopal, \\ Madhya Pradesh 462024, India \\ ${ }^{3}$ Department of Community and Family Medicine, AIIMS, Bhopal, India
}

Correspondence should be addressed to Girish C. Bhatt; drgcbhatt@gmail.com

Received 25 August 2014; Revised 6 November 2014; Accepted 18 November 2014

Academic Editor: Amogh A. Sahasrabuddhe

Copyright (C) 2015 Priyanka Singh et al. This is an open access article distributed under the Creative Commons Attribution License, which permits unrestricted use, distribution, and reproduction in any medium, provided the original work is properly cited.

\begin{abstract}
A prospective observational study was conducted in a tertiary care teaching hospital from August 2008 to August 2009 to explore the independent predictors of adverse outcome in the patients with confirmed/probable viral encephalitis. The primary outcome variable was the incidence of adverse outcomes defined as death or severe neurological deficit such as loss of speech, motor deficits, behavioural problems, blindness, and cognitive impairment. Patients with confirmed or probable viral encephalitis were classified into two groups based on their Z-score of weight-for-age as per WHO growth charts. Group I. Patients with confirmed or probable viral encephalitis with weight-for-age (W/A) Z-scores below -2SD were classified as undernourished. Group II. Patients with confirmed or probable viral encephalitis were classified as having normal nutritional status (weight-for-age $Z$-score $>-2 S D$ ). A total of 114 patients were classified as confirmed or probable viral encephalitis based on detailed investigations. On multivariate logistic regression, undernutrition (adjusted OR: 5.05; 95\% CI: 1.92 to 13.44) and requirement of ventilation (adjusted OR: 6.75; 95\% CI: 3.63 to 77.34) were independent predictors of adverse outcomes in these patients. Thus, the results from our study highlight that the association between undernutrition and adverse outcome could be extended to the patients with confirmed/probable viral encephalitis.
\end{abstract}

\section{Introduction}

A wide range of viruses are implicated as a cause of acute viral encephalitis either in sporadic or in outbreak forms. Enteroviruses, flaviviruses, and herpes simplex, Chandipura, and West Nile viruses are some of the common causes of viral encephalitis [1-3]. Eastern Uttar Pradesh region of India is facing regular outbreaks of the encephalitis since 1978. Children below the age of 14 years were the most vulnerable population and despite mass JE vaccination following this epidemic, the death toll continued to rise. A change in the clinical pattern of encephalitis was observed in this region with JE positivity of about 5-17\% [4]. Isolates from 306 patients with acute encephalitis during an outbreak of viral encephalitis in northern India identified enterovirus in about 21.6 percent of cases. Further sequencing and phylogenetic analyses of PCR products from $89.3 \%$ specimens showed similarity with EV-89 and EV-76 sequences [5].

A potential biochemical mechanism that could adversely affect seizure threshold (in patients with epilepsy), particularly the effect of malnutrition on inhibitory neurotransmitter and electrolyte, has been worked out where supportive evidence from animal research and epidemiological findings in children has been discussed [6]. A lot of research has been done in the past showing the interrelationship between poor nutritional status, infection, and immunity but no such work has been published regarding viral encephalitis or other infectious diseases. A recent study from India by Bhargava 
et al. [7] has shown a high prevalence (more than $85 \%$ ) of undernutrition in patients with pulmonary tuberculosis at diagnosis and an increased risk of death among patients with undernutrition. However, there are no global data regarding the effect of undernutrition on the outcome of patients with viral encephalitis. Therefore, we conducted this study to find out an association between the status of nutrition of encephalitis patients and the clinical outcomes of the disease.

\section{Methods}

2.1. Design and Study Population. This prospective observational study was performed in a tertiary care centre of north India from August 2008 to August 2009. The study protocol was approved by institutional ethics committee. After obtaining written consent from parents, all consecutive patients, aged 2 months to 10 years, admitted to a tertiary care teaching hospital with AES [8] characterized by pleocytosis, an absence of bacteria upon culture of CSF, and some or all of the following features, fever, sensorium changes (such as confusion, disorientation, drowsiness, stupor, coma, convulsions, and abnormal behavior), ataxia, limb paralysis, hemiplegia, and specific cranial nerve dysfunction plus confirmed or probable viral etiology, were enrolled for the study. A detailed examination was done in a precoded performa and various samples were sent for microbiological investigations. For confirmation of viral etiological CSF, serum, throat swab, and stool samples were tested. CSF was also subjected to nested RTPCR or real-time PCR for detecting presence of enterovirus or JEV genome. All the samples were stored at $-20^{\circ} \mathrm{C}$ before sending them to the National Institute of Virology (NIV). Based on these investigations patients were divided into the following.

Patients with Confirmed Viral Etiological Agents. Those patients with positive CSF PCR for JEV or enteroviruses and/or IgM antibodies against JEV in CSF were grouped as confirmed viral encephalitis.

Probable Viral Etiological Agents. Those patients with presence of enterovirus in stool or throat samples and absence of other viruses in CSF were classified as probable viral etiological agents.

Based on CSF examination, bacterial culture, and other examinations, patients with bacterial meningitis, tuberculous meningitis, cerebral malaria, and typhoid fever were excluded. Causes of the consciousness level caused by factors other than infections (such as hypoglycaemia, haemorrhage, infarction, and other metabolic causes) were excluded from the study. Patients with suspected viral encephalitis in which no etiological agent could be identified were also excluded from the study.

Further, patients with confirmed or probable viral encephalitis were classified into two groups based on their $Z$-score of weight-for-age as per World Health Organization (WHO) charts [9].

Group I. Patients with confirmed or probable viral encephalitis with weight-for-age (W/A) $Z$-scores below-2SD were classified as ill-nourished [9].
Group II. Patients with confirmed or probable viral encephalitis with normal nutritional status (weight-for-age $Z$-score $>-2 \mathrm{SD}$ ) were classified as normally nourished.

2.2. Outcome Variables. The primary outcome variable was the incidence of adverse outcomes defined as death or severe neurological deficit such as loss of speech, motor deficits, behavioural problems, blindness, and cognitive impairment. We also evaluated other sociodemographic and clinical factors for association with adverse outcome

The factors which were evaluated in our study were prehospital factors such as rural or urban background, socioeconomic status, time interval between onset of symptoms and hospital arrival time, and total duration of hospital stay. Factors at admission which were evaluated include demographic characteristics of the population such as age, sex, gender, presence of undernutrition, clinical features, and investigations.

All the patients were followed up until death or discharge, whichever came first. All the baseline characteristics were collected at the time of admission. For determining risk factors we compared the predefined factors of the children who died or had severe neurological deficit during hospital stay.

Patients in both groups received treatment as per the standard protocol for encephalitis while patients in undernutrition group received recommended treatment for undernutrition [8].

2.3. Statistical Analysis. Statistical analysis was done by using SPSS-21 software. Sociodemographic and clinical characteristics were described using counts and proportions for categorical variables and mean and standard deviation for numerical variables. Chi-square test was used to test difference among malnourished and normal groups. A $P$ value of less than 0.05 was considered statistically significant. Univariate logistic regression analysis was performed to test association of various factors with outcome, namely, favourable versus adverse. Then statistically significant factors (Table 1) and certain known predictors like pallor, place residence, and hospitalization interval were also included in multivariate logistic regression model [4]. Stepwise forward conditional model was used for identifying independent predictors. Hosmer-Lemeshow Goodness of Fit test was used for testing fit of model.

\section{Results}

A total of 1286 patients were screened during this period and 114 patients were classified as confirmed or probable viral encephalitis based on detailed investigations. Out of these 80 patients were grouped as undernutrition (group I) and 34 patients were classified as normally nourished (group II). The mean age of presentation was $5.26 \pm 2.5$ years (mean \pm standard deviation) in group 1 and $5 \pm 2$ years in group II. At the time of admission the statistically significant difference between two groups was found for variables, namely, swelling all over the body, pallor, edema, signs of dehydration, 
TABLE 1: Clinical and laboratory parameters in group I and group II.

\begin{tabular}{|c|c|c|c|}
\hline Variables & $\begin{array}{l}\text { Group I } \\
(n=80)\end{array}$ & $\begin{array}{l}\text { Group II } \\
(n=34)\end{array}$ & $P$ value \\
\hline \multicolumn{4}{|l|}{ Clinical features } \\
\hline Rashes & $20(25)$ & $06(17.64)$ & 0.392 \\
\hline Swelling & $37(46.25)$ & $08(23.52)$ & 0.023 \\
\hline Headache & $14(17.50)$ & $04(11.76)$ & 0.442 \\
\hline Unconsciousness & $58(72.5)$ & $25(73.5)$ & 0.910 \\
\hline Altered behavior & $22(27.5)$ & $09(26.5)$ & 0.910 \\
\hline GTCS & $59(73.75)$ & $23(67.6)$ & \multirow{3}{*}{0.537} \\
\hline Focal seizures & $10(12.5)$ & $07(20.6)$ & \\
\hline No seizure & $11(13.75)$ & $04(11.76)$ & \\
\hline Difficulty in breathing & $19(23.75)$ & $07(20.6)$ & 0.713 \\
\hline Pallor & $22(27.5)$ & $03(8.82)$ & 0.027 \\
\hline Pedal oedema & $37(46.3)$ & $08(23.52)$ & 0.023 \\
\hline Signs of dehydration & $20(25.0)$ & None & 0.0007 \\
\hline \multicolumn{4}{|l|}{ GCS score } \\
\hline $3-6$ & $44(55.0)$ & $15(44.2)$ & \multirow{3}{*}{0.529} \\
\hline $7-10$ & $19(23.7)$ & $11(32.4)$ & \\
\hline$>10$ & $17(21.3)$ & $08(23.5)$ & \\
\hline Hepatomegaly & $36(45.0)$ & $18(52.9)$ & 0.437 \\
\hline Splenomegaly & $33(41.25)$ & $32(94.12)$ & $<0.001$ \\
\hline Tachycardia & $48(60.0)$ & $13(38.2)$ & 0.033 \\
\hline \multicolumn{4}{|l|}{$\begin{array}{l}\text { Laboratory } \\
\text { investigations }\end{array}$} \\
\hline CSF cell count & & & 0.074 \\
\hline $6-100$ & $68(85)$ & $24(70.5)$ & \\
\hline$>100$ & $12(15)$ & $10(29.5)$ & \\
\hline $\begin{array}{l}\text { SGPT raised } \\
(15-40 \mathrm{U} / \mathrm{L})\end{array}$ & $50(62.5)$ & $25(73.3)$ & 0.256 \\
\hline $\begin{array}{l}\text { Blood urea raised } \\
(20-40 \mathrm{mg} \\
\text { per } 100 \mathrm{~mL})\end{array}$ & $55(68.7)$ & $04(11.76)$ & 0.0001 \\
\hline ECG changes & $20(25)$ & $09(26.4)$ & 0.868 \\
\hline $\begin{array}{l}\text { Abnormal CT scan } \\
\text { findings }\end{array}$ & $6 / 33$ & $03 / 12$ & 0.613 \\
\hline
\end{tabular}

tachycardia, and raised blood urea present in undernutrition group (Table 1). A total of 54 patients were classified as confirmed JE, 32 patients as confirmed enteroviruses, and 28 patients as probable enterovirus encephalitis.

3.1. Complications and Outcome. A total of 24 patients expired during hospital stay, 21 in group I and 3 in group II. The most common complications present in these patients were aspiration pneumonia (12), gastrointestinal bleeding (11), congestive heart failure (8), peripheral vascular failure (8), and cerebral herniation (6). A total of 37 patients required ventilation, the most common indications being respiratory failure followed by shock and low Glasgow coma scale. The mean duration of ventilation was 34 (29) hours in both groups. Severe neurological deficit was present in 49 patients (41 in group I and 08 in group II). Thus incidence of adverse outcome in undernourished group was 62/80 (77.5\%; $95 \%$ CI: 67.2 to 87.8 ) which was higher than that in normally nourished group [11/34 (32.4\%; 95\% CI: 19.1 to 49.2$)]$.

3.2. Risk Factor for Poor Outcome. On univariate analysis for association of various factors with outcome categories, presence of malnutrition, edema, signs of meningeal irritation, gastrointestinal bleed, respiratory distress, and need for ventilator support were statistically significantly associated with adverse outcome (Tables 2 and 3). On multivariate analysis by forward conditional method, only presence of undernutrition (adjusted OR: 5.05; 95\% CI: 1.92 to 13.44) and requirement of ventilation within 48 hours (adjusted OR: 6.75; 95\% CI: 3.63 to 77.34 ) were independently associated with adverse outcomes. Hosmer-Lemeshow Goodness of Fit test was nonsignificant $(P=0.956)$ indicating fit of model, Omnibus Test of Model Coefficients on step 2 was significant $(P=0.001)$, and Nagelkerke R Square was 0.408 .

\section{Discussion}

Our study found that undernutrition and requirement of ventilator support within 48 hours of admission are independent predictors of adverse outcome. To the best of our knowledge, the association between undernutrition and poor outcomes in patients with viral encephalitis has not been previously reported. A study on long term outcomes of Japanese encephalitis (JE) virus in central Sarawak, Malaysia, has shown poor perfusion, Glasgow coma scale $\leq 8$, and more than two witnessed seizures as predictors of poor outcome at hospital discharge [10]. Other studies have shown younger age, higher body temperature, high white cell count in cerebrospinal fluid, and deep coma at hospital admission, altered sensorium, and focal neurologic deficit as predictor of poor outcomes in patients with JE [11, 12].

Previous studies have shown age, lower Glasgow coma scale (GCS) at admission, pallor, peripheral vascular failure, cerebral edema, status epileptics, thrombocytopenia, and requirement of ventilator support as independent predictors of mortality in the patients with viral encephalitis $[4,13,14]$. In a recent retrospective review of the patients with central nervous system infections which included patients with tuberculous meningitis, viral encephalitis, pyogenic meningitis, and fungal meningitis admitted to neurological critical care unit of a tertiary care centre, duration of hospital stay and mechanical ventilation were found to be independent predictors of mortality [15].

About $70 \%$ of the patients in our study had undernutrition (weight-for-age $Z$-score <-2SD). The prevalence of malnutrition in India is 43\% [16] and Uttar Pradesh region is one of the worst regions affected with about $40 \%$ of its children being underweight and 56.8\% stunted [17].

Nutritional status can be improved in the community by a number of interventions such as initiation of early breastfeeding and complementary feeding through nutrition counseling with some additional measures necessary in food insecure settings [18, 19]. The excess morbidity and mortality associated with undernutrition owed to the 
TABLE 2: Univariate and multivariate logistic regression test to identify independent predictors of adverse outcome in patients of viral encephalitis.

\begin{tabular}{|c|c|c|c|}
\hline \multicolumn{4}{|c|}{${ }^{*}$ Univariate analysis } \\
\hline Variable & Number $(n)$ & $\begin{array}{l}\text { Odds ratio } \\
(95 \% \mathrm{CI})\end{array}$ & $P$ value \\
\hline Undernutrition & $\begin{array}{l}\text { Yes } 80 \\
\text { No } 34\end{array}$ & $6.27(2.6-15.10)$ & $<0.001$ \\
\hline $\begin{array}{l}\text { Requirement of } \\
\text { ventilation }\end{array}$ & $\begin{array}{l}\text { Yes } 37 \\
\text { No } 77\end{array}$ & $\begin{array}{c}19.93 \\
(4.47-88.75)\end{array}$ & $<0.001$ \\
\hline $\begin{array}{l}\text { Rural } \\
\text { Urban }\end{array}$ & $\begin{array}{l}94 \\
20\end{array}$ & $1.8(0.70-4.89)$ & 0.216 \\
\hline $\begin{array}{l}\text { Abdominal } \\
\text { pain }\end{array}$ & $\begin{array}{l}\text { Yes } 19 \\
\text { No } 95\end{array}$ & $\begin{array}{c}3.88 \\
(1.059-14.21)\end{array}$ & 0.0041 \\
\hline Splenomegaly & $\begin{array}{l}\text { Yes } 65 \\
\text { No } 49\end{array}$ & $\begin{array}{c}0.497 \\
(0.225-1.094)\end{array}$ & 0.082 \\
\hline $\begin{array}{l}\text { Congestive heart } \\
\text { failure }\end{array}$ & $\begin{array}{l}\text { Yes } 21 \\
\text { No } 93\end{array}$ & $\begin{array}{c}2.21 \\
(0.075-6.55)\end{array}$ & 0.152 \\
\hline $\begin{array}{l}\text { Peripheral vascular } \\
\text { failure }\end{array}$ & $\begin{array}{c}\text { Yes } 11 \\
\text { No } 103\end{array}$ & $\begin{array}{c}6.88 \\
(0.85-55.83)\end{array}$ & 0.071 \\
\hline $\begin{array}{l}\text { Requirement of } \\
\text { ICU care }\end{array}$ & $\begin{array}{l}\text { Yes } 40 \\
\text { No } 74\end{array}$ & $\begin{array}{c}5.67 \\
(2.13-15.10)\end{array}$ & 0.001 \\
\hline Edema & $\begin{array}{l}\text { Yes } 45 \\
\text { No } 69\end{array}$ & $3.21(1.38-7.48)$ & 0.007 \\
\hline $\begin{array}{l}\text { Signs of } \\
\text { meningeal irritation }\end{array}$ & $\begin{array}{l}\text { Yes } 10 \\
\text { No } 104\end{array}$ & $\begin{array}{c}6.09 \\
(0.74-49.92)\end{array}$ & 0.092 \\
\hline $\begin{array}{l}\text { Aspiration } \\
\text { pneumonia }\end{array}$ & $\begin{array}{l}\text { Yes } 15 \\
\text { No } 99\end{array}$ & $\begin{array}{c}4.60 \\
(0.98-21.46)\end{array}$ & 0.053 \\
\hline $\begin{array}{l}\text { Acute renal } \\
\text { failure }\end{array}$ & $\begin{array}{l}\text { Yes } 25 \\
\text { No } 89\end{array}$ & $\begin{array}{c}1.74 \\
(0.66-4.60)\end{array}$ & 0.260 \\
\hline $\begin{array}{l}\text { Gastrointestinal } \\
\text { bleeding }\end{array}$ & $\begin{array}{l}\text { Yes } 16 \\
\text { No } 98\end{array}$ & $\begin{array}{c}2.99 \\
(0.80-11.17)\end{array}$ & 0.104 \\
\hline $\begin{array}{l}\text { Prehospitalization } \\
\text { interval }\end{array}$ & $\begin{array}{l}\leq 3 \text { days } 33 \\
>3 \text { days } 81\end{array}$ & $\begin{array}{c}0.63 \\
(0.27-1.44)\end{array}$ & 0.278 \\
\hline $\begin{array}{l}\text { Undernutrition by } \\
\text { requirement of } \\
\text { ventilation (interaction) }\end{array}$ & & $\begin{array}{c}32.55 \\
(4.24-249.8)\end{array}$ & 0.001 \\
\hline
\end{tabular}

\begin{tabular}{lccc}
\hline \multicolumn{4}{c}{${ }^{*}$ Multivariate analysis } \\
Variable & Variable & Variable & Variable \\
\hline Undernutrition & Yes 80 & 5.05 & \multirow{2}{*}{0.001} \\
Requirement of & No 34 & $(1.9-13.44)$ & \\
ventilation & Yes 37 & 16.75 & $<0.001$ \\
\hline
\end{tabular}

CI: confidence interval; OR: odds ratio.

* Based on logistic regression test.

\#Variables excluded after forward variable selection.

impairment of host defense mechanisms, which predisposes them to infectious diseases [20]. Thus, our study suggests that this association between undernutrition and adverse outcomes extends to the patients with viral encephalitis (JE and enteroviruses).

Requirement of ventilation within 48 hours of admission was found to be strongly associated with adverse outcome in our study. These findings are consistent with previous reports of critically ill patients with all cause encephalitis [13]. This finding indicates that physicians must assess the need for
TABLE 3: Neurological deficit present in two groups at the time of discharge.

\begin{tabular}{lccccc}
\hline $\begin{array}{l}\text { Residual neurological } \\
\text { deficits }\end{array}$ & \multicolumn{2}{c}{ Group I } & \multicolumn{2}{c}{ Group II } & \multirow{2}{*}{ Number } \\
& Nulue & Number & $\%$ & \\
\hline $\begin{array}{l}\text { Behavioral problem } \\
\text { Involuntary }\end{array}$ & 41 & 51.25 & 06 & 17.6 & 0.0045 \\
movements & 13 & 16.25 & 00 & 00 & 0.009 \\
Hypertonia & 11 & 13.75 & 00 & 00 & 0.03 \\
Speech deficit & 16 & 20.00 & 01 & 02.9 & 0.02 \\
Abnormal gait & 18 & 22.50 & 02 & 05.8 & 0.03 \\
Hemiparesis & 03 & 3.7 & 01 & 2.9 & 1.0 \\
\hline
\end{tabular}

mechanical ventilation early with ongoing evaluation of the need for respiratory support [15].

Our study has certain limitations. As our primary objective was to explore risk factors associated with poor outcomes, considering feasibility of data collection in limited time period, we have accrued consecutive samples and no formal sample size calculations were done. As Japanese encephalitis and enteroviruses are the two most common etiological agents responsible for major outbreak of viral encephalitis in this region, risk factors for poor outcomes of patients suffering from these two organisms were included. Moreover, the evaluation of patients for chronic malnutrition and micronutrient status could not be done.

The strengths of our study are as follows: being the first study to show the association of undernutrition and poor outcomes in the patients with viral encephalitis; sampling of all consecutive patients coming to our institute which is only tertiary centre catering these patients, thus making selection bias less likely; inclusion of confirmed or probable viral encephalitis patients making results more disease specific.

This study has some important implications: undernutrition was highly prevalent in the patients with viral encephalitis and was associated with poor outcomes in these patients. It is an established fact that the economic condition of the family has a huge impact on the nutritional status of the children [18]. Malnutrition commonly affects all groups in a community, but infants and young children are most vulnerable because of their high nutritional requirements for growth and development. A comprehensive programme approach to improving complementary feeding practices including timely introduction of age-appropriate and hygienically prepared complementary foods, counseling for caregivers on feeding and care practices, optimal use of locally available foods, improving access to quality foods for poor families through social protection schemes and safety nets, and the provision of fortified foods and micronutrient $[18,19]$ is the need of the hour. Proper supportive care is the mainstay of treatment in cases of enterovirus or Japanese encephalitis as no specific treatment is presently available [21-24]. Further studies are required on long term follow-up and effect of nutritional intervention on the outcomes of the patients with viral encephalitis. 


\section{Conclusion}

Our study found that undernutrition and requirement of ventilator support within 48 hours of admission are independent predictors of adverse outcome. Thus, the results from our study highlight that the association between undernutrition and adverse outcome could be extended to the patients with confirmed/probable viral encephalitis. Moreover, the results from the present study will be helpful for future design of treatment and preventive strategies of the disease.

\section{Conflict of Interests}

The authors declare that there is no conflict of interests regarding the publication of this paper.

\section{Acknowledgment}

The authors would like to thank Dr. M. M. Gore, Director of the National Institute of Virology, Gorakhpur Unit, for providing viral isolation.

\section{References}

[1] C. A. Glaser, S. Gilliam, D. Schnurr et al., "In search of encephalitis etiologies: diagnostic challenges in the California Encephalitis Project; 1998-2000," Clinical Infectious Diseases, vol. 36, no. 6, pp. 731-742, 2003.

[2] P. G. E. Kennedy, "Viral encephalitis," Journal of Neurology, vol. 252, no. 3, pp. 268-272, 2005.

[3] P. G. E. Kennedy, "Viral encephalitis: causes, differential diagnosis, and management," Journal of Neurology, Neurosurgery \& Psychiatry, vol. 75, no. 1, pp. i10-i15, 2004.

[4] G. C. Bhatt, V. P. Bondre, G. N. Sapkal et al., "Changing clinicolaboratory profile of encephalitis patients in the eastern Uttar Pradesh region of India," Tropical Doctor, vol. 42, no. 2, pp. 106108, 2012.

[5] G. N. Sapkal, V. P. Bondre, P. V. Fulmali et al., "Enteroviruses in patients with acute encephalitis, Uttar Pradesh, India," Emerging Infectious Diseases, vol. 15, no. 2, pp. 295-298, 2009.

[6] R. Hackett and T. Iype, "Malnutrition and childhood epilepsy in developing countries," Seizure, vol. 10, no. 8, pp. 554-558, 2001.

[7] A. Bhargava, M. Chatterjee, Y. Jain et al., "Nutritional status of adult patients with pulmonary tuberculosis in rural central India and its association with Mortality," PLoS ONE, vol. 8, no. 10, Article ID e77979, 2013.

[8] WHO, "Recommended standards for surveillanceof selected vaccine-preventable disease," Tech. Rep. WHO/V\&B/03.01, 2006, http://www.who.int/vaccines-documents/DocsPDF06/ 843.pdf.

[9] "The WHO growth chart-World Health Organization," http:// www.who.int/childgrowth/publications/WHO_growth_charts .pdf.

[10] H. O. Mong, P. Lewthwaite, F. L. Boon et al., "The epidemiology, clinical features, and long-term prognosis of Japanese encephalitis in central Sarawak, Malaysia, 1997-2005," Clinical Infectious Diseases, vol. 47, no. 4, pp. 458-468, 2008.

[11] A. Rayamajhi, R. Singh, R. Prasad, B. Khanal, and S. Singhi, "Clinico-laboratory profile and outcome of Japanese encephalitis in Nepali children," Annals of Tropical Paediatrics, vol. 26, no. 4, pp. 293-301, 2006.
[12] D. Luo, J. Song, H. Ying, R. Yao, and Z. Wang, "Prognostic factors of early sequelae and fatal outcome of Japanese encephalitis," The Southeast Asian Journal of Tropical Medicine and Public Health, vol. 26, no. 4, pp. 694-698, 1995.

[13] K. T. Thakur, M. Motta, A. O. Asemota et al., "Predictors of outcome in acute encephalitis," Neurology, vol. 81, no. 9, pp. 793800, 2013.

[14] V. T. Le, T. Q. Phan, Q. H. Do et al., "Viral etiology of encephalitis in children in southern Vietnam: results of a one-year prospective descriptive study," PLoS Neglected Tropical Diseases, vol. 4, no. 10, article e854, 2010.

[15] U. K. Misra, J. Kalita, and S. K. Bhoi, "Spectrum and outcome predictors of central nervous system infections in a neurological critical care unit in India: a retrospective review," Transactions of the Royal Society of Tropical Medicine and Hygiene, vol. 108, no. 3, Article ID tru008, pp. 141-146, 2014.

[16] "Progress for children report-a statistical review," 2007, http:// www.unicef.org/india/media_3766.htm.

[17] UNICEF, Statistics India, statistics.html\#100 http://www.unicef .org/infobycountry/india.

[18] "Children in India 2012-A statistical appraisal," http://mospi .nic.in/mospi_new/upload/Children_in_India_2012.pdf.

[19] UNICEF India-Nutrition, 2014, http://www.unicef.org/india/ nutrition.html.

[20] P. C. Melby, B. Chandrasekar, W. Zhao, and J. E. Coe, "The hamster as a model of human visceral leishmaniasis: progressive disease and impaired generation of nitric oxide in the face of a prominent Th1-like cytokine response," The Journal of Immunology, vol. 166, no. 3, pp. 1912-1920, 2001.

[21] R. Kumar, P. Tripathi, and A. Rizvi, "Effectiveness of one dose of SA 14-14-2 vaccine against Japanese encephalitis," The New England Journal of Medicine, vol. 360, no. 14, pp. 1465-1466, 2009.

[22] G. C. Bhatt, J. Sankar, and K. P. Kushwaha, "Use of intravenous immunoglobulin compared with standard therapy is associated with improved clinical outcomes in children with acute encephalitis syndrome complicated by myocarditis," Pediatric Cardiology, vol. 33, no. 8, pp. 1370-1376, 2012.

[23] M. Kakkar, E. T. Rogawski, S. S. Abbas et al., "Acute encephalitis syndrome surveillance, Kushinagar District, Uttar Pradesh, India, 2011-2012," Emerging Infectious Diseases, vol. 19, no. 9, pp. 1361-1367, 2013.

[24] S. Jain, B. Patel, and G. C. Bhatt, "Enteroviral encephalitis in children: clinical features, pathophysiology, and treatment advances," Pathogens and Global Health, vol. 108, no. 5, pp. 216222, 2014. 


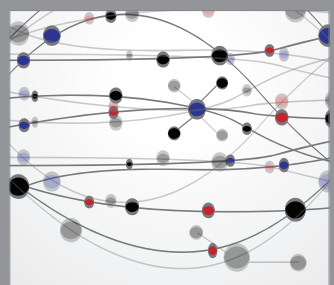

The Scientific World Journal
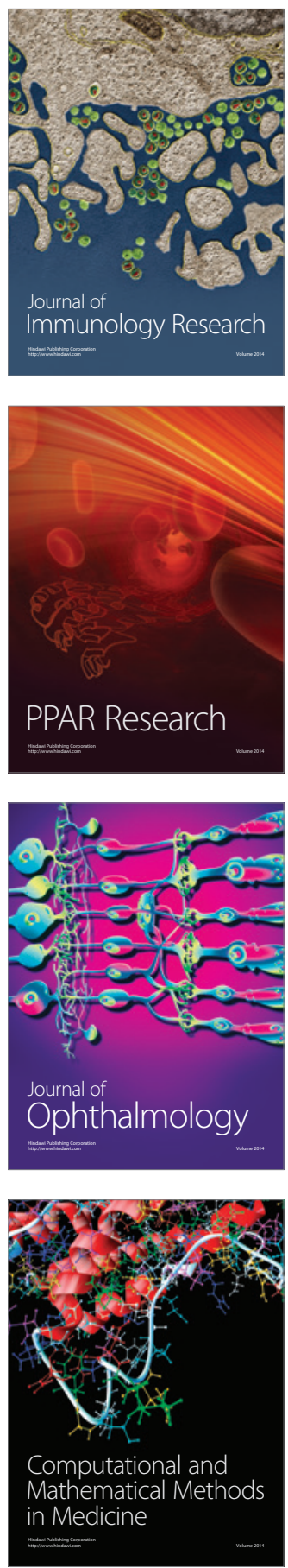

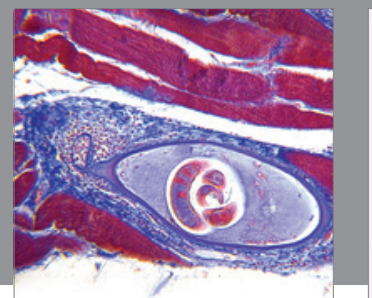

Gastroenterology

Research and Practice
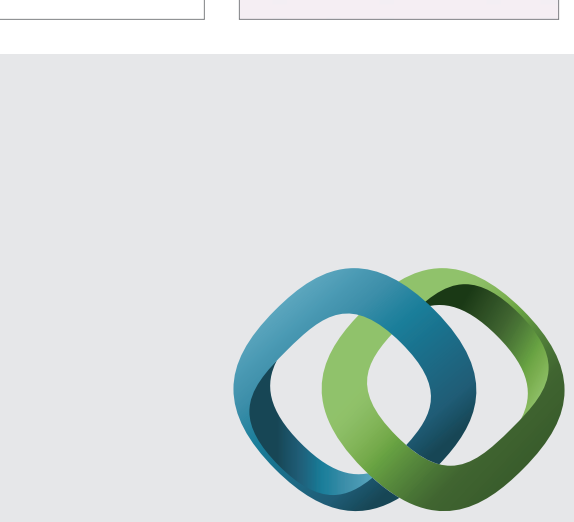

\section{Hindawi}

Submit your manuscripts at

http://www.hindawi.com
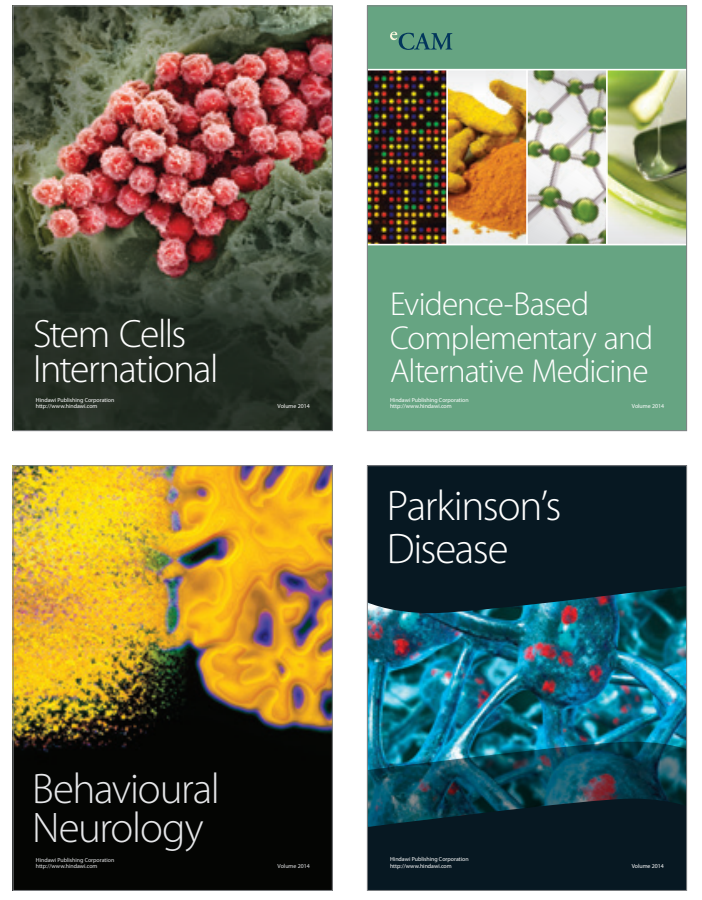
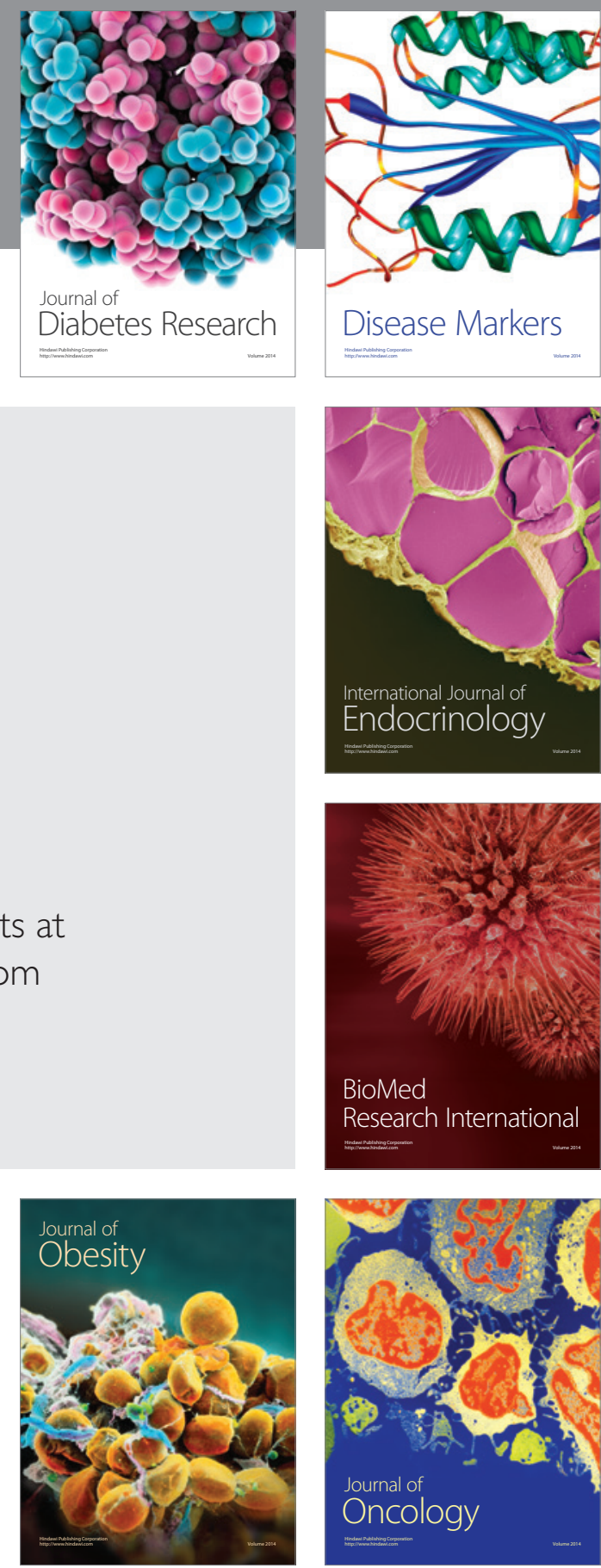

Disease Markers
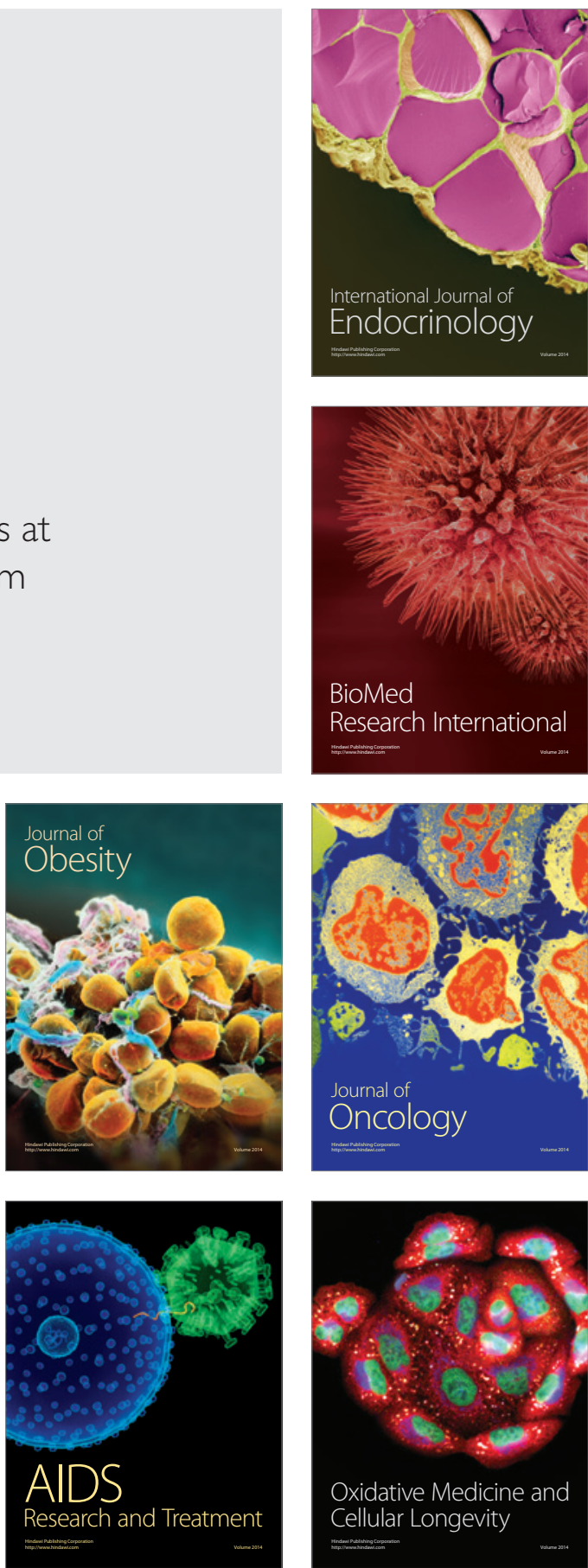